\title{
ANALISIS GAYA BELAJAR MATEMATIKA PADA SISWA KELAS VII SMP NEGERI OEBAKI
}

\author{
Antjeliasari K. V. Daik ${ }^{1}$, Alfonsia M. Abi2*, Yusak I. Bien ${ }^{3}$ \\ ${ }^{1}$ Mahasiswa Pendidikan Matematika STKIP Soe, ${ }^{2,3}$ STKIP Soe \\ fonsaabi14@gmail.com
}

Diterima: 30 April 2020 Disetujui: 08 Juni 2020 Dipublikasikan: 31 Juli 2020

\begin{abstract}
ABSTRAK
Penyebab rendahnya nilai matematika dikarenakan minat dan perhatian siswa sangat rendah. Banyak siswa yang merasa pelajaran matematika sangat sulit untuk dimengerti dan dipahami serta tidak adanya kemauan bagi siswa untuk mengulang di rumah, setiap pelajaran yang diterimanya di sekolah, dan guru belum memperhatikan gaya belajar siswa. Salah satu karakteristik belajar yang berkaitan dengan menyerap, mengolah,dan menyampaikan informasi adalah gaya belajar siswa. Gaya belajar merupakan modalitas belajar yang sangat penting. Informasi terkait karakteristik gaya belajar siswa sangat penting bagi guru untuk meningkatkan kualitas pembelajarannya. Siswa juga akan lebih mudah memotivasi dirinya dalam pembelajaran.Tujuan penelitian ini untukmengetahui gaya belajar yang dimiliki siswa kelas VII SMP Negeri Oebaki dan untuk mengetahui gaya belajar yang paling dominan, yang dimiliki oleh para siswa kelas VII di SMP Negeri Oebaki tahun ajaran 2017/2018. Jenis penelitian ini adalah penelitian deskriptif kualitatif. Instrumen penelitian yang digunakan adalah angket, wawancara dan observasi, dari hasil penelitian yang diperoleh gaya belajar yang dimiliki siswa kelas VII SMP Negeri Oebaki adalah gaya belajar visual, auditorial, kinestetik, dan gaya belajar yang paling dominan adalah gaya belajar kinestetik.
\end{abstract}

Kata kunci: auditorial, gaya belajar matematika, kinestetik, visual.

\begin{abstract}
The reason of getting low mark in mathematics is due to the lack of students' interest and attention. Many students feel that mathematics is hard to be learnt and to be understood as well as there is unwillingness effort to review every lesson at home along with teachers' unawareness of students' learning style. One of the characteristics in learning style that related to absorption, preparation and delivery of information is the students' learning style. Learning style forms the important modality in study. The information about characteristic of students' learning style is very important for teachers to increase the quality of learning itself and students will be easier to motivate themselves in learning as well. The aim of this research is to know the learning style of seventh grade students in SMP N Oebaki in the academic year 2017/2018. The method of this research is descriptive qualitative method and the research instrument that used are questionnaires, interview and observation. The result of this study shows that the students have visual, auditory, and kinesthetic learning style, and the dominant learning style of the students is kinesthetic learning style.
\end{abstract}

Keywords: auditory, mathematical learning style, kinesthetic, visual.

\section{Pendahuluan}

Upaya meningkatkan kualitas sumber daya manusia melalui pendidikan dapat dilakukan pada berbagai lembaga pendidikan salah satunya adalah lembaga pendidikan formal (sekolah). Sekolah merupakan jalur pendidikan yang berjenjang yaitu dari pendidikan dasar sampai perguruan tinggi dan terdapat kegiatan belajar mengajar didalamnya serta berbagai mata pelajaran yang harus diterapkan dan salah satunya adalah matematika (Ahmadi, 2014: 81).

Matematika merupakan salah satu disiplin ilmu yang mendasari perkembangan teknologi modern, karena matematika mempunyai peranan penting dalam berbagai disiplin ilmu lain dan mempunyai pengaruh besar dalam memajukan daya pikir manusia (Depdiknas, 2006). Oleh karena itu, tidak dapat disangkal bahwa matematika mendasari ilmu pengetahuan dan teknologi.Pembelajaran matematika di sekolah perlu ditekankan agar hasil belajar yang diperoleh relevan dengan kehidupan sehari-hari dan dapat diaplikasikan sesuai dengan kebutuhan. 


\section{Range: Jurnal Pendidikan Matematika Vol. 2 No. 1 Tahun 2020 Antjeliasari K. V. Daik, dkk}

Rendahnya mutu pendidikan terutama pada pendidikan di sekolah dasar dan menengah, diakibatkan masih banyak siswa cenderung kurang menggemari pelajaran matematika bahkan mereka cenderung tidak tertarik belajar matematika dan mengganggap bahwa pembelajaran matematika itu sulit.Hal seperti ini juga terjadi di SMP Negeri Oebaki.Berdasarkan hasil wawancara dengan salah seorang guru matematika dan beberapa siswa di SMP Negeri Oebakidapat diketahui bahwarata-rata hasil belajar matematika siswa masih tergolong rendahdibandingkan dengan Kriteria KentuntasanMinimal (KKM) yang telah ditetapkan oleh pihaksekolahuntuk mata pelajaran matematika.

Penyebab rendahnyanilai matematika dikarenakan minat dan perhatian siswa sangat rendah. Banyak siswa yang merasa pelajaran matematika sangat sulit untuk dimengerti dan dipahami serta tidak adanya kemauan bagi siswa untuk mengulang dirumah, setiap pelajaran yang diterimanya di sekolah, dan guru belum memperhatikan gayabelajar siswa.Iriani \& Leni(2013), Anas \& Munir (2013) menyatakan terdapat pengaruh yang signifikan antara gaya belajar dan hasil belajar siswa.

Gaya belajar adalah gaya yang dipilih seseorang untuk mendapatkan informasi atau pengetahuan dalam suatu proses pembelajaran. Gaya belajar merupakan modalitas belajar yang sangat penting. Gaya belajar dibagi dalam tiga kelompok yaitu gaya belajar visual, auditory, dan kinesthetic. Gaya belajar visual belajar dengan cara melihat, gaya belajar Auditory belajar dengan cara mendengar, sedangkan kinesthetic belajar dengan cara terlibat langsung atau melakukan (Subini, 2011: 17).

Pengetahuan tentang gaya belajar siswa merupakan suatu hal yang penting, baik oleh siswa itu sendiri maupun bagi guru. Seorang siswa bisa lebih memaksimalkan kemampuannya dalam belajar guna meningkatkan prestasinya. Sementara bagi guru, dengan adanya pengetahuan tersebut akan membantu seorang guru dalam memilih metode pembelajaran yang sesuai dengan minat siswa, dapat menciptakan gaya belajar yang menyenangkan bagi siswa, menimbulkan motivasi belajar dan mengurangi konflik yang timbul sebagai akibat dari belajar.

\section{Metode Penelitian}

Metode yang digunakan dalam penelitian ini adalah metode deskriptif kualitatif. Penelitian ini dilaksanakan di SMP Negeri Oebaki, Kecamatan Noebeba, Kabupaten Timor Tengah Selatan pada semester ganjil tahun ajaran 2017/2018. Instrumen yang digunakan berupa angket, wawancara, observasi dan dokumentasi. Angket yang digunakan adalah angket gaya belajar dengan skala likert. Sumber data dalam penelitian ini adalah siswa kelas VII SMP Negeri Oebaki tahun ajaran 2017/2018 sebanyak 19 orang. Teknik pengumpulan data yang digunakan adalah triangulasi teknik. Teknik analisis data yang digunakan adalah analisis data kualitatif mengikuti model Miles dan Huberman. Uji keabsahan data yang digunakan dalam penelitian ini adalah metode triangulasi teknik (Sugiyono, 201:365)

\section{Hasil Penelitian dan Pembahasan}

Penelitian ini bertujuan untuk mengetahui gaya belajar matematika yang dimiliki siswa kelas VII SMP Negeri Oebaki dan yang paling dominan. Gaya belajar yang dilihat adalah visual, auditorial dan kinestetik. Angket yang diedarkan terdiri dari 8 item pernyataan yang berkaitan dengan gaya belajar visual, 14 item pernyataan gaya belajar auditorial, dan 10 item pernyataan yang berkaitan dengan gaya belajar kinestetik. Pernyataan-pernyatan tersebut disusun secara acak untuk melihat konsistensi dari jawaban setiap siswa. Masing-masing siswa wajib memberi jawaban terhadap ke-32 pernyataan yang ada. Hasil isian angket siswa kemudian dirangkum, dianalisis serta dibuat kategorinya oleh peneliti. Pengkategorian dilakukan berdasarkan kategori item pertanyaan yang sudah ditentukan. Hasil analisis respon siswa pada angket dihitung menggunakan analisis frekuensi yang menunjukkan bahwa siswa yang memiliki gaya belajar visual sebesar $21,05 \%$, gaya belajar auditorial sebesar $31,58 \%$ dan gaya belajar kinestetik sebesar 47,47\%. Dominasi kecenderungan gaya belajar siswa adalah gaya belajar kinestetik. Hasil analisisnya digambarkan pada tabel 1 dan gambar 1.

Tabel 1. Hasil Analisis Frekuensi 


\begin{tabular}{cc}
\hline Gaya Belajar & Persentase \\
\hline Visual & 21.05 \\
Auditorial & 31.58 \\
Kinestetik & 47.47 \\
\hline
\end{tabular}

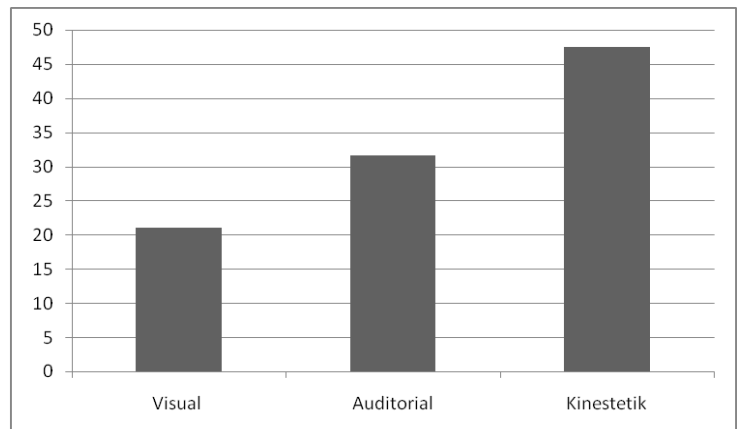

Gambar 1. Persentase Tabel 1

Siswa yang memiliki gaya belajar visual seperti yang dikatakan De Porter \& Hernacki (2000) menunjukkan sikap rapi dan teratur saat mengerjakaan soal matematika, selalu mengutamakan penampilan saat melakukan presentasi di depan kelas, menggunakan gerak tubuh saat tampil melakukan presentasi pelajaran matematika di depan kelas, lebih gampang menyelesaikan tugas matematika menggunakan objek berbentuk gambar, menggerakkan bibir saat membaca pelajaran matematika, mengingat/menghafal pelajaran matematika dengan cara berjalan dan melihat, dan selalu teliti dalam menyelesaikan soal matematika. Berdasarkan hasil temuan, siswa yang memiliki gaya belajar visual menunjukkan sikap rapi dan teratur, selalu mementingkan penampilan dalam hal pakaian ataupun penampilan keseluruhan, cenderung menggunakan gerakan tubuh saat mengungkapkan sesuatu, lebih mudah memahami materi pembelajaran yang dikemas menarik menggunakan ilustrasi seperti gambar, diagram, peta warna-warni, selalu memperhatikan gerak bibir seseorang yang berbicara kepadanya, selalu memvisualisasikan sesuatu untuk mengingat yang sudah dilihat.

Hasil observasi menunjukkan siswa dengan gaya belajar visual ini menunjukkan sikap seperti yang dijelaskan oleh De Porter Hernacki (2000). Sedangkan pada hasil wawancara diperoleh bahwa mereka yang memiliki gaya belajar visual ketika belajar matematika lebih memahami dengan melihat (membaca) dengan keras sambil menggunakan jari untuk menandai, senang mencatat, senang belajar pada suasana yang tenang tetapi juga tidak mudah terganggu jika ada keributan, jarang berdiskusi di saat sementara belajar, menyukai pemandangan/gambar, lebih suka membaca sendiri bukan dibacakan serta akan lebih paham ketika belajar dengan alat peraga. Ini dikarenakan mereka suka menggunakan indra penglihatan mereka ketika belajar dengan cara membaca dan melihat. Hal ini tampak pada transkrip wawancara dengan siswa A18.

$P \quad$ :Bagaimana cara anda belajar dan memahami pelajaran matematika?

A18 :saya belajar dan memahami pelajaran matematika dengan cara melihat dan mencatat

$P \quad:$ Anda lebih cepat memahami pelajaran matematika dengan membaca sendiri atau dibacakan oleh orang lain?

A18 :Untuk lebih cepat memahami pelajarn matematika saya harus baca sendiri, kalu orang lain yang membacakan saya tidak paham, bingung dan juga tidak mengerti.

$P \quad$ :Dalam pembelajara nmatematika, Apakah anda belajar melalui mendengar dan mengingat apa yang didiskusikan dari pada yang dilihat?

A18 :Saya mengingat dengan cara melihat dan mendengar, saya jarang berdiskusi

$P \quad$ :Antara musik dan seni rupa, mana yang paling anda sukai? bagaimana dengan matematika? apakah musik dan seni juga digunakan? 


\section{Range: Jurnal Pendidikan Matematika Vol. 2 No. 1 Tahun 2020 Antjeliasari K. V. Daik, dkk}

\section{A18 :Saya lebih menyukai seni rupa, misalnya menggambar dan mewarnai gambar objek matematika dan juga pemandangan.}

Pada siswa yang memiliki gaya belajar auditorial menunjukkan sikap berbicara dengan cepat saat memjawab pertanyaan yang terkait dengan matematika, banyak bicara, berdiskusi pada saat belajar matematika, menjelaskan panjang lebar pada saat belajar matematika, mendengarkan musik ketika belajar/mengerjakan tugas matematika, lebih paham pembelajaran matematika hanya dengan mendengarkan penjelasan guru, menggerakkan bibir pada saat membaca pelajaran matematika, bersuara pada saat membaca pelajaran matematika, mudah terganggu jika ada keributan, dan pembicara yang fasih (De Porter \& Hernacki, 2000). Berdasarkan hasil temuan, siswa yang memiliki gaya belajar auditorial cenderung banyak bicara dan berceritra, berdiskusi, bertanya, menjelaskan sesuatu dengan panjang lebar, menyukai musik, lebih cepat menyerap materi pembelajaran dengan cara mendengarkan, menggerakkan bibir mereka dengan mengucapkan tulisan di buku ketika membaca, suka mengerjakan tugas kelompok. Hasil ini didukung oleh wawancara yang dilakukan dengan siswa yang bergaya belajar auditorial. Dijelaskan bahwa mereka akan memahami matematika dengan cara mendengar, mencatat dan menghafal. Siswa senang jika materinya dibacakan oleh orang lain baik itu teman maupun guru, senang belajar di tempat yang tenang karena mereka mudah terganggu jika ada keributan, akan lebih mengingat materi ketika kegiatan diskusi, cepat bosan jika duduk diam, menghafal dan membaca dengan suara keras agar bisa didengarnya kembali, serta tidak suka belajar dengan menggunakan alat peraga. Siswa dengan gaya belajar auditorial menggunakan indra pendengarannya secara maksimal ketika belajar. Transkrip wawancara dengan siswa A06 yang bergaya belajar auditorial sebagai berikut.

$P \quad$ :Bagaimana cara anda belajar dan memahami pelajaran matematika?

A06 :Saya belajar dan memahami pelajaran matematika dengan cara duduk diam, mendengar dan mencatat.

P : :Anda lebih cepat memahami pelajaran matematika dengan membaca sendiri atau dibacakan oleh orang lain?

A06 : Saya lebih cepat mengerti jika dibacakan oleh teman atau guru

$P \quad$ :Dalam pembelajaran matematika Apakah anda belajarmelalui mendengar dan mengingat apa yang didiskusikan daripada yang dilihat?

A06 :Saya belajar matematika dengan cara duduk diam mendengar dan juga mencatatsaya juga terganggu jika ada keributan.

$P \quad:$ Pada saat membaca pelajaran matematika, apakah anda sering menggunakan jari tangan untuk menunjuk? Alasannya!

A06 :Saya sering menggunakan jari untuk menunjuk ketika membaca pelajaran matematika, agar cepat mengerti.

$P \quad$ :Pada saat proses pembelajaran matematika berlangsung, apakah anda bisa duduk tenang untuk waktu yang lama?

A06 :Saya tidak bisa duduk diam dalam waktu yang lama, sering-sering ijin keluar kelas karena bosan.

Siswa yang memiliki gaya belajar kinestetik menunjukkan sikap berbicara dengan lambat saat menjawab pertanyaan dari guru matematika, lebih tertarik untuk berolah raga dari pada belajar matematika, lebih paham pembelajaran matematika dengan bentuk permainan (game), belajar dengan menggunakan banyak latihan soal matematika yang dikerjakan, lebih paham materi matematika melalui alat peraga, lebih suka belajar matematika dengan menggunakan alat peraga, menggambar objek-objek matematika, dan tidak bisa duduk tenang dalam waktu yang lama selama mengikuti pelajaran matematika di kelas (De Porter \& Hernacki, 2000). Berdasarkan hasil temuan, siswa yang memiliki gaya belajar kinestetik berbicara dengan perlahan (lambat), menyukai permainan dan olah raga, belajar melalui praktik, suka menggunakan objek yang nyata sebagai alat bantu belajar, menggunakan jari sebagai 


\section{Range: Jurnal Pendidikan Matematika Vol. 2 No. 1 Tahun 2020 Antjeliasari K. V. Daik, dkk}

penunjuk ketika membaca, sulit untuk berdiam diri. Hal ini lihat dari hasil observasi dan wawancara. Transkrip wawancara dengan siswa A06 sebagai berikut.
$P$
: Pada saat membaca pelajaran matematika, apakah anda sering menggunakan jari tangan untuk menunjuk? Alasannya!
A06 : Saya selalu menggunakan jari untuk menunjuk, agar jangan salah baca.
$P \quad$ : Pada saat proses pembelajaran matematika berlangsung, apakah anda bisa duduk tenang untuk waktu yang lama?
A06 : Saya tidak bisa duduk tenang dalam waktu yang lama karena cepat bosan.
$P \quad$ : Apakah anda sering meluangkan waktu untuk berolahraga?
A06 : Saya sering meluangkan waktu untuk berolah raga, saya suka olah raga voli
$P \quad:$ : Apakah anda suka belajar matematika dengan menggunakan alat peraga?
A06 : Saya suka belajar menggunakan alat peraga atau praktik
$P \quad$ : Bagaimana cara anda mengingat rumus-rumus matematika?
A06 : Saya menghafal dengan cara berjalan dan melihat

Wawancara yang dilakukan terhadap 6 orang siswa yang terdiri dari 2 orang siswa dengan gaya belajar visual,2 orang dengan gaya belajar auditorial, dan 2 orang dengan gaya belajar kinestetik. Siswa dengan gaya belajar visual lebih memahami pelajaran matematika dengan cara melihat, pembaca yang tekun, tidak mudah terganggu pada keributan, menyukai seni rupa, duduk diam dalam waktu yang lama. Siswa dengan gaya belajar auditorial menunjukkan sikap memahami pelajaran matematika dengan cara duduk diam dan mendengarkan, lebih senang dibacakan daripada membaca sendiri, mudah terganggu pada keributan, membaca sambil menggerakan bibir, menghafal dengan suara keras, dan tidak bisa duduk diam dalam waktu yang lama. Sedangkan siswa dengan gaya belajar kinestetik menunjukkan sikap belajar menggunakan alat peraga, mengingat dengan cara praktik atau melakukan, sering menggunakan jari tangan untuk menunjuk pada saat membaca pelajaran matematika, menyukai olah raga, belajar matematika menggunakan alat peraga, dan cepat memahami pelajaran matematika jika menggunakan alat peraga.

Terdapat beberapa perbedaan antara hasil pengisian angket, wawancara dan observasi. Meski angket dan wawancara sama, hasil observasi justru berbanding terbalik. Dalam pengisian angket dan kegiatan wawancara siswa cenderung pada gaya belajar visual dan auditori, sedangkan pada kegiatan observasi siswa cenderung pada gaya belajar kinestetik.Perbedaan yang terjadi pada pengisian angket dipengaruhi oleh kondisisiswa yang tidak santai, karena pada saat pengisian angket ada pihak sekolah yang hadir, sehingga siswa merasa canggung saat mengisi angket.

Siswa yang diwawancarai menunjukkan sikap memahami pelajaran matematika dengan cara melihat, tidak mudah terganggu jika ada keributan dan menyukai seni rupa, siswa ini cenderung pada gaya belajar visual. Siswa yang menunjukkan sikap memahami pelajaran matematika dengan duduk diam dan mendengarkan, mudah terganggu pada keributan, menghafal dengan suara keras,dan tidak bisa duduk diam dalam waktu yang lama, siswa ini cenderung pada gaya belajar auditorial. Setelah diobservasi siswa yang cenderung pada gaya belajar visual dan auditorial, cenderung pada gaya belajar kinestetik yang menunjukkan sikap belajar menggunakan alat peraga, mengingat dengan cara praktik atau melakukan, sering menggunakan jari tangan untuk menunjuk kalimat pada saat membaca pelajaran matematika, dan menyukai olah raga.

Terjadi perbedaan antara hasil angket, observasi dan wawancara, setelah di wawancarai lebih mendalam diperoleh informasi bahwa mereka di pengaruhi oleh berbagai faktor baik dari dalam diri siswa itu sendiri (internal) maupun dari luar diri siswa (eksternal). Faktor internal meliputi faktor jasmaniah (fisiologis), baik yang bersifat bawaan maupun yang diperoleh seperti penglihatan, pendengaran, struktur tubuh, dan sebagainya. Faktor pikologis baik yang bersifat bawaan maupun yang di peroleh terdiri atas faktor intelektif yang meliputi potensial yaitu kecerdasan dan bakat, kecakapan nyata yaitu prestasi yang dimiliki. Faktor non intelektif yaitu unsur-unsur kepribadian tertentu seperti sikap, kebiasaan, gaya belajar, minat, kebutuhan, motivasi, emosi, penyesuaian diri. Faktor eksternal meliputi faktor sosial yang terdiri dari lingkungan keluarga, lingkungan sekolah, dan lingkungan masyarakat. Lingkungan keluarga 


\section{Range: Jurnal Pendidikan Matematika Vol. 2 No. 1 Tahun 2020 Antjeliasari K. V. Daik, dkk}

meliputi, pola asuh atau kebiasaan yang diterapkan dari orang tua, fasilitas rumah, dan fasilitas belajar. Lingkungan sekolah meliputi gangguan dari pihak lain, dan pola pembelajaran yang diberikan oleh guru, sedangkan dari lingkungan masyarakat meliputi pengaruh dari budaya lainseperti adat istiadat, ilmu pengetahuan, dan teknologi kesenian.

Kesimpulan yang diperoleh adalah siswa yang memiliki gaya belajar visual cenderung belajar melalui apa yang mereka lihat. Siswa dengan gaya belajar visual selalu melihat bahasa tubuh dan ekspresi wajah gurunyauntuk mengerti materi pelajaran, selalu duduk di depan agar dapat melihat dengan jelas, berpikir menggunakan gambar-gambar dan belajar lebih cepat dengan menggunakan tampilan-tampilan visual seperti diagram, buku pelajaran bergambar, dan video. Siswa yang memiliki gaya belajar auditorial dapat belajar lebih cepat dengan menggunakan diskusi verbal dan mendengarkan apa yang guru katakan, mereka dapat mencerna dengan baik informasi yang di sampaikan melalui tone suara, pich (tinggi rendahnya), kecepatan berbicara pada dan hal-hal auditori lainnya. Informasi tertulis terkadang sulit di terima oleh siswa bergaya belajar auditori. Siswa bergaya belajar seperti ini biasanya menghafal lebih cepat dengan membaca teks dengan keras dan mendengarkan kaset, sedangkan siswa yang memiliki gaya belajar kinestetik belajar melalui bergerak, menyentuh dan melakukan. Siswa seperti ini tidak tahan untuk duduk berlama-lama mendengarkan pelajaran dan merasa bisa belajar lebih baik jika prosesnya disertai kegiatan fisik.

Guru menggunakan berbagai metode belajar mengajar yang didominasi oleh metode ceramah secara umum. Siswa yang duduk diam dan mendengarkan dengan tekun hingga akhir cenderung memiliki gaya belajar auditorial. Media pembelajaran menggunakan gambar (poster) dan peta (diagram), memberikan kesempatan bagi siswa yang mempunyai kencenderungan belajar secara visual. Ketika metode yang digunakan lebih banyak melibatkan keterampilan siswa, siswa yang mempunyai kecenderungan gaya belajar kinestetik akan sangat antusias. Siswa dengan gaya belajar visual, yang memegang peranan penting adalah mata atau penglihatan (visual). Mereka cenderung belajar melalui apa yang mereka lihat. Siswa yang bertipe auditori mengandalkan kesuksesan belajarnya melalui telinga (alat pendengarannya). Siswa yang mempunyai gaya belajar kinestetik belajar melalui bergerak, menyentuh dan melakukan.Hal tersebut dilakukan terus menerus pada saat proses pembelajaran di kelas berlangsung agar guru dapat melihat bagaimana reaksi siswa terhadap setiap model pembelajaran, sehingga lambat laun guru akan mudah memahami dan akan mengetahui kecenderungan gaya belajar mereka.

Gaya belajar anak sangat berpengaruh pada hasil belajar mereka dan mereka akan merasakannya kelak ketika dewasa nanti, manfaat dari bimbingan yang diberikan kepada mereka. Kesuksesan guru atau orang tua dalam mendidik adalah ketika guru atau orang tua tahu benar gaya belajar anak, lalu menerapkan pola pembelajaran yang sesuai dengan gaya belajar tersebut. Para guru atau orang tua menganggap anak sama. Akhirnya gaya mengajar anak harus sesuai dengan gaya belajar guru atau orang tua. Jika disadari hal inilah yang menjadi salah satu penyebab kegagalan guru atau orang tua dalam mendidik.

\section{Kesimpulan}

Berdasarkan hasil dan pembahasan dapat disimpulkan bahwa siswa kelas VII SMP Negeri Oebaki memiliki gaya belajar visual, auditorial dan juga kinestetik dengan sebaran yang tidak merata. Gaya belajar mereka didominasi kinestetik. Yang artinya bahwa gaya belajar sebagian besar siswa dipengaruhi oleh gerakan atau kinestik. Oleh karena itu, guru harus mampu memahami gaya belajar siswa kemudian menyesuaikan gaya atau strategi mengajarnya sehingga proses pembelajaran optimal. Untuk itu perlu disarankan untuk penelitian selanjutnya perlu diselidiki apakah model atau metode yang digunakan dengan mempertimbangkan gaya belajar yang paling dominan memberikan hasil belajar yang optimal atau tidak. Sedangkan bagi para siswa hendaknya mengenali gaya belajar mereka masing-masing sehingga mampu memanfaatkannya dalam belajar matematika. 


\section{Range: Jurnal Pendidikan Matematika Vol. 2 No. 1 Tahun 2020 Antjeliasari K. V. Daik, dkk}

\section{Daftar Pustaka}

Ahmadi, R. (2014). “Pengantar Pendidikan: Asas dan Filsafat Pendidikan”. Yogyakarta:Ar-Ruzz Media.

Anas, A. \&Munir N. P. (2013). "Pengaruh gaya belajar vak terhadap hasil belajarMatematika siswa". Prosiding Seminar Nasional, 2 (1): 233 -896.

Depdiknas.2006. “Permendiknas Nomor 22 Tahun 2006 Tentang Standar Isi Sekolah Dasar”. Jakarta: Depdiknas.

DePorter, B \& Hernacki, M. (2000). "Quantum Learning: Membiasakan Belajar Nyaman dan Menyenangkan”. Bandung: Kaifa.

Iriani, D. \& Leni, M. 2013. "Identifikasi Gaya Belajar dan Pengaruhnya terhadap Hasil Belajar Siswa pada Materi kubus dan Balok di Kelas VIII SMP 2 Kerinci”.Prosiding Semirata, Universitas Lampung :109-114.

Subini, N. (2011). “Rahasia Gaya Belajar Orang Besar, Cetakan 1”. Yogyakarta: Javalitera.

Sugiyono. (2011). "Metode Penelitian Kombinasi (Mixed Methods)”. Bandung: Alfabeta. 